Article

\title{
What is Private Land Stewardship? Lessons from Agricultural Opinion Leaders in North Carolina
}

\author{
Shari L. Rodriguez ${ }^{1, *(1)}$, M. Nils Peterson ${ }^{2}$, Frederick W. Cubbage ${ }^{3}$, Erin O. Sills ${ }^{3}$ and \\ Howard D. Bondell ${ }^{4}$ \\ 1 Department of Forestry and Environmental Conservation, Clemson University, Clemson, SC 29634, USA \\ 2 Fisheries, Wildlife, and Conservation Biology Program, Department of Forestry and Environmental \\ Resources, North Carolina State University, Raleigh, NC 27695, USA; nils_peterson@ncsu.edu \\ 3 Department of Forestry and Environmental Resources, North Carolina State University, Raleigh, NC 27695, \\ USA; fred_cubbage@ncsu.edu (F.W.C.); sills@ncsu.edu (E.O.S.) \\ 4 School of Mathematics and Statistics, University of Melbourne, Melbourne 3010, Australia; \\ bondell@unimelb.edu.au \\ * Correspondence: slrodri@clemson.edu; Tel.: 186-4656-0430
}

Received: 15 November 2017; Accepted: 15 January 2018; Published: 24 January 2018

\begin{abstract}
The development of private land is a significant conservation concern globally. To conserve the ecosystem services associated with private lands, conservationists must understand landowner conceptions of stewardship and its role in decisions about land and natural resources. We began addressing this need with a survey of North Carolina Farm Bureau county advisory board members in North Carolina $(n=735)$. Nearly all respondents self-identified as stewards of the land $(97 \%)$. More respondents indicated their stewardship responsibility was owed to future generations ( $87 \%$ ) and family $(77 \%)$, rather than to the community (41\%) or society (26\%). Respondents associated stewardship more with using natural resources wisely (78\%) than leaving natural resources untouched $(31 \%)$. Plans to bequeath land to relatives, the importance of soil conservation, and past participation in conservation programs were the most consistent predictors of how respondents viewed stewardship. Our results suggest that stewardship may be more effective when framed more as a benefit to family and future generations than to society and the community. Similarly, stewardship may be more effective for achieving conservation as opposed to the preservation of natural resources.
\end{abstract}

Keywords: stewardship; private lands; natural resources; conservation; North Carolina

\section{Introduction}

Conservation in private land plays a pivotal role in global sustainability [1]. Further, due to the privatization of water, forests, farm land, and fisheries in South America, Africa, and Asia [2-7], conservation on private land is an issue of growing importance. In the United States (US), privately owned lands (hereafter private lands) constitute $99 \%$ of the nation's croplands, $61 \%$ of grasslands and pasture, and $56 \%$ of forests [8] and provide habitat for more than $75 \%$ of endangered species $[9,10]$. Historically, conservation efforts have focused on public lands, leaving the private lands that dominate the US landscape at risk of unsustainable land management practices, and urban sprawl and development. Finding ways to encourage sustainable decision-making and conservation practices on private lands (e.g., prescribed fire, conservation of endangered species) is, therefore, paramount to maintaining the ecosystem services provides by private lands [11,12].

Perhaps the most well-known initiatives for encouraging sustainable land management practices that facilitate the conservation of private lands and their associated natural resources and ecosystem services are government conservation incentive programs, such as the Conservation Reserve Program (CRP), whereby private landowners are paid to implement the specific conservation requirements of 
the program. The CRP (among other similar programs), has a continuing established presence as a land stewardship program in most states in the US [13]. The CRP, specifically, has enrolled over 20 million acres of land each year in the US between 1988 and 2012 [14] and as of 2014, has 25.6 million acres of US land enrolled [15]. Although such programs have provided incentives for private landowners to implement conservation practices such as forest and wetland restoration, installation of conservation buffers, and enhanced wildlife habitat [16], there simply is not enough money to pay all landowners to conserve their land. As such, it is critical to find ways other than direct payments to persuade private landowners to promote sustainability on their land. One way may be to appeal to landowners' sense of stewardship.

Private Land Stewardship (PLS) plays a vital role in natural resource management through its effects on the future of our nation's food supplies, the health of our farm workers [16], and access to and quality of drinking water [17]. Previous literature suggests that PLS constitutes a vital part of property rights value orientations and can influence landowner willingness to adopt socially desirable land management practices without financial incentives [18,19].

Despite the essential role it plays in conservation, PLS is poorly defined [20]. Definitions of PLS vary widely, but most include conservation of natural resources with consideration of both the future and society at large. Some definitions of stewardship include: "managing private property to protect long-term environmental sustainability" ([18], p. 591); appreciation of and respect for the land as a basis for prosperity and quality of life [21]; knowing, restoring, protecting and connecting to the land [22]; promoting and maintaining sustainable fisheries [23]; conserving wildlife populations [24], and a land ethic [25]. Worrell and Appleby ([20], p. 263) describe stewardship as "the responsible use (including conservation) of natural resources in a way that takes full and balanced account of the interests of society, future generations, and other species, as well as of private needs, and accepts significant answerability to society". One of few descriptions of stewardship given by the US government states that it is a "concept that helps define appropriate human interactions with the natural world" ([26], p. 1, Chapter 5). The common thread among most concepts of PLS is a person or persons caring for the environment, not for the benefit of themselves, but for future generations, driven by voluntary personal ethics, rather than by legal obligations [27].

Perhaps given the diverse definitions for the term, little information exists regarding how private landowners themselves view PLS. Peterson and Horton [28] identified PLS as a central theme in disputes between Texas ranchers and the US Fish and Wildlife Service over a golden-cheeked warbler (Setophaga chrysoparia) habitat. Peterson et al. [29] found that Latinos in the Lower Rio Grande Valley of Texas self-identified as stewards of the land, associated stewardship with property maintenance, and felt that stewardship was owed to their families, rather than to the larger community. In a study of residents living near New Mexico's Los Alamos National Laboratory, the wise use of natural resources and preservation of natural resources were among the activities most associated with stewardship [30]. Davies and Hodge [31] identified five different views on stewardship among landowners in the UK: ecosystem-focused, managerial and technologically-centered, goods-maximizing, community tradition-protecting, and lifestyle-focused perspectives. Only respondents with ecosystem- or lifestyle-focused perspectives demonstrated a clear sense of responsibility to others. Both groups felt responsible to future generations, and the ecosystem-focused group felt responsible to nature itself for conservation.

Effective efforts to promote voluntary conservation on private lands hinge on an understanding of landowner views of stewardship. Thus, to better understand conceptions of stewardship, we conducted a case study of North Carolina Farm Bureau (NCFB) county board members throughout the state. County advisory board members provide an important sample because they are elected representatives of NCFB members and constitute $86 \%$ of all private farm land owners and operators in North Carolina (personal communication, Chester Lowder). North Carolina (NC) provides a good context for PLS research as $80 \%$ of the land is privately owned [32], including $25 \%$ that is farm land [33], and $33 \%$ that is non-industrial private forest land [34]. 
Between 1986 and 2015, the CRP enrolled nearly 3.5 million acres of farm land in NC and paid out nearly US \$190 million farm landowners and operators in NC between 1987 and 2016 [35]. Farm landowners and operators, therefore, make decisions and implement land management practices that are critical in determining the fate of the state's natural resources, and many have participated in, and even more are familiar with, incentive programs designed to promote stewardship [36]. As such, the objectives of this study were to determine: (1) if the NCFB county advisory board members consider themselves to be stewards of the land; (2) what motivates them to be stewards of the land; (3) what activities they associate with PLS (i.e., stewardship definitions); (4) if they feel payments for conservation practices would make them better stewards of the land; and (5) what variables (demographics, land tenure and use, perceptions, and experiences) predict stewardship motivations and definitions.

\section{Materials and Methods}

Our population of interest was all members of NCFB county advisory boards throughout NC. The NCFB is the state's largest farm organization. During the study timeframe, the NCFB's membership was more than 500,000 members statewide, representing $86 \%$ of all farm land owners in the state (personal communication, Chester Lowder). The NCFB has more members than any other state Farm Bureau organization nationwide, and is dedicated to supporting farming communities throughout the state [37]. County advisory board members are member-elected and are key opinion leaders and decision-makers on farm issues at the county level. As such, this purposive sample represented farm landowners literally, in addition to being a representative sample demographically.

A self-administered questionnaire was delivered to a monthly meeting of each advisory board in the 100 NC counties by NCFB staff or the principal investigator between March and October 2009. We promoted design validity by obtaining reviews by experts from NC State University and the NC Cooperative Extension, and by pretesting with NCFB county advisory board members in seven counties $(n=61)$. Since no major edits to the survey instrument resulted from the pretest, the pretest responses were used in the study. The study design and materials were approved by the North Carolina State University Institutional Review Board prior to the study implementation (IRB\# 17-09-01).

The main areas of inquiry in our questionnaire included PLS, property rights value orientations, land use and characteristics, land ownership information, and socio-demographic information. We drew from previous literature to develop answer categories for both stewardship motivations and activities [20,31]. To learn if respondents considered themselves to be stewards, we asked: "Do you consider yourself to be a steward of the land?" (objective 1). If respondents answered "yes", they were then asked for more information on motivating factors of their stewardship: "What motivates you to be a steward of the land?" (objective 2). Answer options for the multiple selection questions regarding stewardship motivations were: yourself, your family, your community, society, the land, future generations, and God. We assessed activities respondents associated with stewardship by asking: "What does being a steward of the land mean to you?" (objective 3). Answer options for multiple selection questions regarding activities associated with stewardship were: controlling pollution, implementing conservation farming practices, maintaining your property, maintaining high crop production, using natural resources wisely, and leaving natural resources untouched (non-anthropocentric motives) [38,39]. For both questions, respondents were asked to indicate all motivations and activities that applied (multiple selection). To assess how payments for conservation practices might affect their stewardship, we asked: "Would payments for conservation practices help you be a better steward of the land?" (objective 4), with answer options yes, no, and maybe.

We addressed objective 5 using multiple logistic regression. Each of the seven stewardship motivations and six stewardship activities were used as dependent variables. We attempted to predict respondents' stewardship motivations and activities using nine independent variables (summarized in Table 1). We included PAST PARTICIPATION in conservation incentive programs (participation in the previous 5 years; we also asked which programs they had participated in in that time period) and 
about IMPORTANCE of soil conservation because many conservation programs promote stewardship, and many do so with a focus on soil conservation. To assess respondents' plans for their land after their death, we asked respondents, "What plans do you have for your property upon your death?" Answer options included: (1) transfer it to relatives; (2) sell it; (3) donate it to a land trust; and (4) unsure. We included respondents' plans for their land upon death as proxy for how they view responsibility to family and future generations. Thus, for the purposes of analysis, we created a binary variable indicating whether respondents plan to transfer their land to relatives (TRANSFER TO RELATIVES).

Table 1. Summary of independent variables used in logistic regression to predict stewardship motivations and activities from a survey of North Carolina Farm Bureau county advisory board members from 93 North Carolina counties (March-October 2009). PRO: property rights orientations.

\begin{tabular}{|c|c|c|c|c|}
\hline Variable & Variable Type & Description & Mean/\% & SD \\
\hline $\begin{array}{l}\text { PAST PARTICIPATION in } \\
\text { conservation programs }\end{array}$ & Binary & $\begin{array}{l}0=\text { No prior participation in a conservation program; } \\
1=\text { Participation in conservation program in past } 5 \text { years }\end{array}$ & $41 \%$ & - \\
\hline TRANSFER TO RELATIVES & Binary & $0=$ No, $1=$ Yes & $90 \%$ & - \\
\hline PRO & Categorical & $\begin{array}{l}\text { Sum of Likert scale responses to seven statements, each with } \\
7 \text {-point Likert scales }(-3=\text { Strongly disagree, } \\
0=\text { Neutral, and } 3=\text { Strongly agree); sum range is }-21 \text { (social } \\
\text { responsibility orientation) to } 21 \text { (individual rights orientation) }\end{array}$ & 7.77 & 6.89 \\
\hline ACRES OWNED & Continuous & Acres owned in North Carolina & 251.85 & 359.97 \\
\hline ROW CROPS & Continuous & Percent of owned land in North Carolina dedicated to row crops & 30.77 & 31.05 \\
\hline INCOME & Continuous & $\begin{array}{l}\text { Total household income (in thousands of US dollars); midpoint of } \\
\text { respondent's } 2008 \text { income bracket }\end{array}$ & 93.71 & 53.47 \\
\hline
\end{tabular}

To measure property rights orientations (PRO), we used a scale designed to capture the respondents' orientation towards individual property rights versus social responsibilities [18]. The PRO variable was included because we expected those respondents who were oriented towards individual property rights would believe they owed stewardship to themselves, whereas respondents who were orientated towards social responsibilities would believe they owed their stewardship to community and society. The questionnaire included seven statements that addressed transfer of land ownership, exclusive use of natural resources, absolute rights to use natural resources, threats to civil liberties, sensitivity to society, obligations to society, and natural resource ownership. For each statement, we asked respondents to indicate their level of agreement on 7-point Likert scales ranging from -3 (strong disagreement) to 3 (strong agreement). Among these 7 statements, 4 are positively narrated statements (with 7 indicating the strongest orientation to individual property rights) and 3 are negatively narrated statements (with 7 indicating the strongest orientation towards social responsibilities). We summed Likert scale responses to the 7 statements, resulting in cumulative scores ranging from -21 (social responsibilities) to 21 (individual rights) [18]. Responses from respondents that did not complete all seven scales were not included in the analysis. We also included total ACRES OWNED in NC, percent of acres owned dedicated to ROW CROPS, INCOME, AGE, and EDUCATION as control variables. Dependent variable selection for regression models depended on previous literature and logistic constraints.

We also collected data on other socio-demographic and land characteristics including gender, race, marital status, primary occupation, acreage of respondents' largest tract of property in NC, how long they had owned their largest tract of property, percent of income generated from their land, how long they planned to maintain land ownership, and if they had a will or living trust in place that described their plans for their land. We used the Statistical Package for Social Sciences (SPSS; 17.0.0, Chicago, IL, USA) to calculate all descriptive and inferential statistics. 


\section{Results}

A total of 735 NCFB county board members in 93 counties participated in our study $(78.3 \%$ compliance rate). Seven of the 100 county boards (Camden, Cherokee, Chowan, Durham, Graham, Lee and Madison) declined participation in the study at the board level and the survey was, therefore, not administered in those counties. Mean respondent age was 58.9 ( $\mathrm{SD}=12.9)$, and most respondents were male $(93.2 \%)$, white $(96.4 \%)$, and married $(88.3 \%)$. Over half of respondents had some college-level education (58.2\%) and primarily worked in a farming -related industry $(77.3 \%)$. Median household income was US $\$ 87,500$, with $56.9 \%$ of respondents indicating that income generated from their property was the primary source (52.9\%) of their 2008 income (means were used when distributions were normal, while medians were used when distributions were skewed). Mean number of acres owned in NC was 251.9 (SD = 360.0). The average size of the largest tract of land owned was 148.5 acres $(\mathrm{SD}=148.5)$, and this land had been in respondents' extended family for 64 years, on average $(\mathrm{SD}=55.2)$. Respondents earned an average of $56.9 \%$ of their total household income from activities on their land. More than $75 \%$ of respondents $(76.2 \%)$ indicated they planned to own their property for 25 years or longer or would maintain it "forever", "until death" or "as long as possible". Ninety percent of respondents indicated they would transfer their land to relatives upon their death, and $70.5 \%$ indicated they had a will or living trust in place that described plans for their property.

Forty-one percent of respondents indicated they had participated in a land conservation program in the past 5 years; the highest participation rates were in the Environmental Quality Incentive Program (EQIP; 36.0\%), CRP (36.4\%), and state agricultural cost share programs for soil and water $(57.2 \%)$. The average rating for IMPORTANCE of soil conservation was 5.96 (SD = 1.6). Respondents' average PRO scale score was $7.8(\mathrm{SD}=6.9)$, indicating an orientation towards individual rights, and most respondents considered soil conservation important (mean rating $=6.0 ; \mathrm{SD}=1.5$ ). The NCFB sample is representative of general farm operators in the state, with no statistically significant differences in mean age or distribution of gender and race [40], but as one might expect given their leadership roles, the NCFB respondents were more likely to work primarily in a farming-related industry $(77.3 \% \mathrm{vs}$. $45.8 \%$ ), and owned more land in NC than the average farm operator in the state (252 acres vs. 160 acres).

Nearly all respondents (97.4\%) self-identified as stewards of the land (objective 1$)$. The largest proportion of respondents identified future generations (86.6\%) as a motivation of their stewardship (objective 2), while the smallest proportion identified society (25.9\%; Figure 1). Maintaining your property was the most common behavior/activity associated with stewardship ( $86.5 \%$; objective 3$)$, while leaving natural resources untouched (30.6\%) was the least (Figure 2).

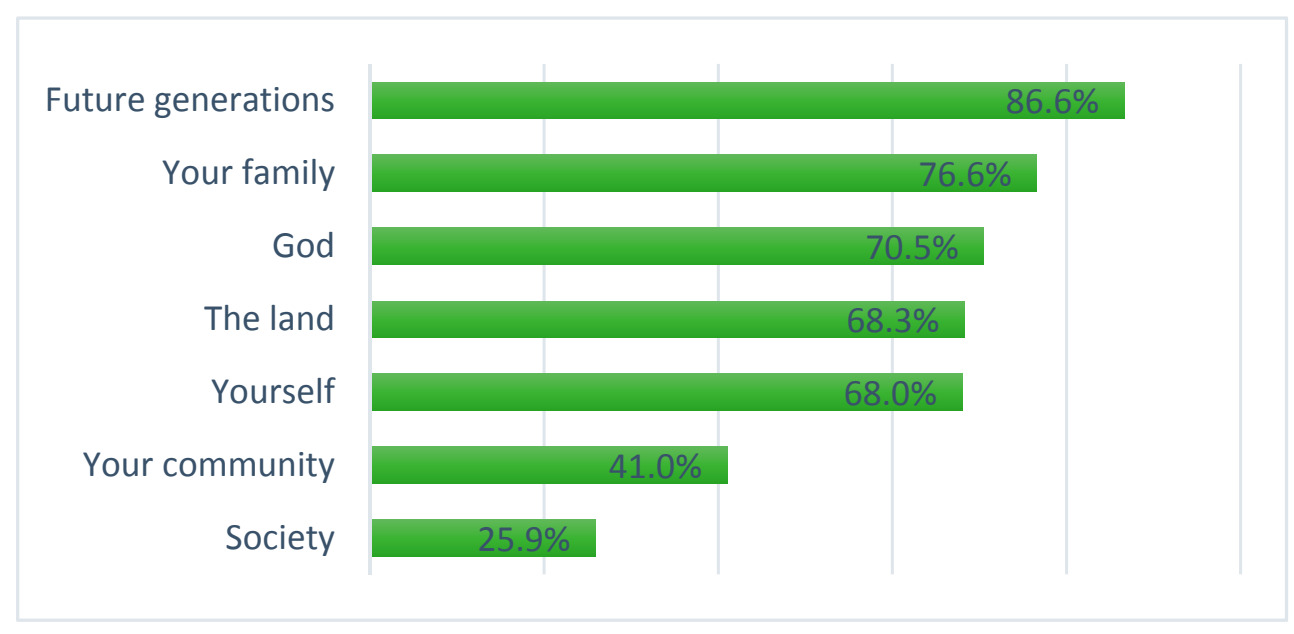

Figure 1. Percent of respondents that identified future generations, your family, God, the land, yourself, your community and your society as motivations for their stewardship. 


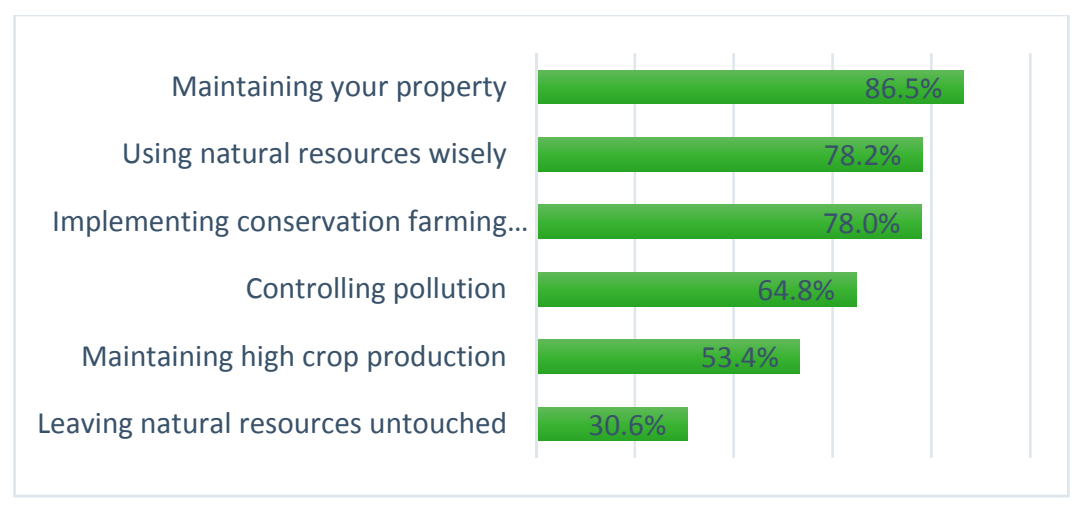

Figure 2. Percent of respondents that considered maintain your property, using natural resources wisely, implementing conservation farming practices, controlling pollution, maintaining high crop production, and leaving natural resources untouched as forms of stewardship.

The majority of respondents (62.7\%) indicated they believed payment for conservation practices would make them better stewards of the land (objective 4). Nearly half of respondents (49.4\%) who had not participated in a conservation program in the previous 5 years associated payments with stewardship. Although motivations for stewardship were similar between respondents who believed payments would make them better stewards (payments) and those who did not feel payments would make them better stewards (no payments), two differences in stewardship motivation were observed. More of those who believed payments would improve their stewardship were more motivated towards stewardship for their own benefit (yourself, $70 \%$; $\mathrm{SD}=0.46)$ and for the benefit of society $(27 \%$; $\mathrm{SD}=0.45)$ than those who believed payments would not improve their stewardship (59\%, SD = 0.49, $\mathrm{t}(539)=-2.47, p=0.014 ;$ and $18 \%, \mathrm{SD}=0.38, \mathrm{t}(539)=-2.11, p=0.035$, respectively). These two subpopulations, however, were largely similar with regards to how they defined stewardship; both groups defined it as maintaining property (85\% payments improve; $87 \%$ payments do not improve), using natural resources wisely (76\% payments improve; $81 \%$ payments do not improve), controlling pollution (66\% payments improve; $64 \%$ payments do not improve), and leaving natural resources untouched (28\% payments improve; $32 \%$ payments do not improve). In contrast, there was disparity in their view on stewardship being defined as implementing conservation farming practices (68\% payments improve, $\mathrm{SD}=0.47 ; 82 \%$ payments do not improve, $\mathrm{SD}=0.39 ; \mathrm{t}(548)=-3.36, p=0.001$ ), and maintaining high crop production ( $46 \%$ payments improve, $\mathrm{SD}=0.50 ; 58 \%$ payments do not improve, $\mathrm{SD}=0.49$; $\mathrm{t}(548)=-2.38, p=0.018)$.

Demographics, land tenure, past experiences, and opinions about the importance of soil conservation predicted respondent beliefs about who or what stewardship was owed to and what activities defined stewardship (objective 5). Stewardship owed to self (yourself) was positively related with TRANSFER TO RELATIVES and negatively related with AGE (Table 2). Owing stewardship to your family was positively predicted by IMPORTANCE of soil conservation only. Owing stewardship to your community was positively predicted by TRANSFER TO RELATIVES and negatively predicted by ROW CROPS. Stewardship owed to society was positively related to IMPORTANCE and TRANSFER TO RELATIVES, and negatively related to PRO. The belief in responsibility of stewardship for the sake of the land was positively related to IMPORTANCE and INCOME. Owing stewardship to future generations was positively related to PAST PARTICIPATION in conservation programs and EDUCATION. The belief that stewardship is owed to God was positively correlated with TRANSFER TO RELATIVES and negatively correlated with ACRES OWNED.

Defining stewardship as controlling pollution was positively predicted by IMPORTANCE of soil conservation only (Table 3). Implementing conservation farming practices was positively correlated with PAST PARTICIPATION in conservation programs and IMPORTANCE. Maintaining property was positively related to IMPORTANCE only. Defining stewardship as maintaining a high crop yield was 
positively correlated with ACRES OWNED and ROW CROPS, and negatively related to EDUCATION. Using natural resources wisely was positively related to PAST PARTICIPATION, while leaving natural resources untouched was positively related to INCOME.

Table 2. Estimated coefficients, odds ratios and standardized odds ratios of logistic regression models predicting who or what respondents believe they owe their stewardship to (motivations; sample size for each model $=346$ ) from a survey of North Carolina Farm Bureau county advisory board members from 93 North Carolina counties (March-October 2009).

\begin{tabular}{|c|c|c|c|c|c|c|c|}
\hline \multirow[b]{2}{*}{ Variable } & \multicolumn{7}{|c|}{ Coefficient (Odds Ratio) [Standardized Odds Ratio] } \\
\hline & Yourself & Your Family & Your Community & Society & The Land & Future Generations & God \\
\hline \multirow{3}{*}{$\begin{array}{l}\text { PAST PARTICIPATION in } \\
\text { conservation programs }\end{array}$} & $0.530 *$ & -0.047 & 0.404 & 0.087 & 0.450 & $1.261 * *$ & 0.269 \\
\hline & (1.699) & $(0.955)$ & (1.498) & (1.091) & (1.569) & (3.529) & (1.308) \\
\hline & [1.297] & {$[0.977]$} & [1.219] & [1.044] & [1.247] & {$[1.855]$} & [1.141] \\
\hline \multirow{3}{*}{$\begin{array}{l}\text { IMPORTANCE of soil } \\
\text { conservation }\end{array}$} & 0.173 & $0.282 * *$ & 0.096 & $0.441 * *$ & 0.302 ** & -0.067 & 0.164 \\
\hline & $(1.188)$ & $(1.325)$ & $(1.101)$ & $(1.554)$ & $(1.353)$ & $(0.935)$ & $(1.178)$ \\
\hline & [1.296] & {$[1.527]$} & [1.155] & [1.938] & [1.573] & {$[0.904]$} & [1.279] \\
\hline \multirow{3}{*}{$\begin{array}{l}\text { TRANSFER TO } \\
\text { RELATIVES }\end{array}$} & 0.770 * & $1.047^{*}$ & 1.441 ** & $2.379 *$ & 0.224 & 0.851 & $1.023 *$ \\
\hline & (2.159) & (2.848) & $(4.223)$ & (10.795) & $(1.251)$ & $(2.341)$ & (2.782) \\
\hline & [1.260] & [1.369] & [1.541] & [2.042] & [1.070] & [1.291] & [1.359] \\
\hline \multirow{3}{*}{ PRO } & 0.001 & -0.019 & -0.018 & $-0.047^{*}$ & -0.006 & -0.012 & -0.004 \\
\hline & (1.001) & $(0.981)$ & $(0.982)$ & $(0.954)$ & $(0.994)$ & $(0.988)$ & $(0.996)$ \\
\hline & [1.007] & [0.877] & [0.883] & [0.723] & [0.960] & [0.921] & [0.973] \\
\hline \multirow{3}{*}{ ACRES OWNED } & -0.067 & -0.062 & 0.040 & -0.012 & -0.061 & 0.030 & $-0.083 *$ \\
\hline & $(0.936)$ & $(0.940)$ & (1.041) & $(0.988)$ & $(0.941)$ & (1.030) & $(0.920)$ \\
\hline & {$[0.786]$} & {$[0.800]$} & [1.155] & [0.958] & [0.803] & [1.114] & [0.742] \\
\hline \multirow{3}{*}{ ROW CROPS } & 0.090 & -0.702 & -0.873 * & -0.112 & 0.576 & -0.511 & 0.145 \\
\hline & (1.094) & $(0.496)$ & $(0.418)$ & $(0.894)$ & (1.779) & $(0.600)$ & (1.156) \\
\hline & [1.028] & {$[0.804]$} & {$[0.763]$} & {$[0.966]$} & [1.195] & {$[0.853]$} & {$[1.046]$} \\
\hline \multirow{3}{*}{ INCOME } & 0.004 & $0.006^{*}$ & 0.002 & 0.001 & $0.007^{* *}$ & 0.004 & 0.003 \\
\hline & (1.004) & $(1.006)$ & $(1.002)$ & (1.001) & $(1.007)$ & (1.004) & (1.003) \\
\hline & [1.239] & [1.379] & [1.113] & [1.055] & [1.454] & [1.239] & [1.174] \\
\hline \multirow{3}{*}{ AGE } & $-0.273 *$ & 0.113 & 0.079 & -0.192 & 0.026 & -0.134 & -0.106 \\
\hline & $(0.761)$ & (1.120) & (1.082) & $(0.825)$ & (1.026) & $(0.874)$ & $(0.900)$ \\
\hline & [0.703] & [1.157] & [1.107] & [0.781] & [1.034] & [0.841] & [0.872] \\
\hline \multirow{3}{*}{ EDUCATION } & 0.356 & -0.184 & 0.172 & 0.287 & 0.120 & $0.758 *$ & 0.127 \\
\hline & (1.427) & (1.203) & (1.188) & (1.333) & (1.128) & (2.135) & (1.135) \\
\hline & [1.239] & [1.117] & [1.109] & [1.188] & [1.075] & [1.577] & [1.079] \\
\hline Constant & -1.352 & -0.489 & $-1.414 *$ & $-4.116 * *$ & $-1.695^{*}$ & 1.204 & -0.583 \\
\hline Nagelkerke R-squared $^{1}$ & 0.131 & 0.074 & 0.088 & 0.107 & 0.109 & 0.125 & 0.068 \\
\hline
\end{tabular}

Table 3. Estimated coefficients, odds ratios and standardized odds ratios of logistic regression models predicting what activities respondents associate with stewardship (sample size for each model = 350) from a survey of North Carolina Farm Bureau county advisory board members from 93 North Carolina counties (March-October 2009).

\begin{tabular}{|c|c|c|c|c|c|c|}
\hline \multirow[b]{2}{*}{ Variable } & \multicolumn{6}{|c|}{ Coefficient (Odds Ratio) [Standardized Odds Ratio] } \\
\hline & $\begin{array}{l}\text { Controlling } \\
\text { Pollution }\end{array}$ & $\begin{array}{l}\text { Implementing } \\
\text { Conservation } \\
\text { Farming Practices }\end{array}$ & $\begin{array}{l}\text { Maintaining } \\
\text { Property }\end{array}$ & $\begin{array}{l}\text { Maintaining } \\
\text { High Crop Yield }\end{array}$ & $\begin{array}{l}\text { Using Natural } \\
\text { Resources Wisely }\end{array}$ & $\begin{array}{c}\text { Leaving Natural } \\
\text { Resources } \\
\text { Untouched }\end{array}$ \\
\hline \multirow{3}{*}{$\begin{array}{l}\text { PAST PARTICIPATION in } \\
\text { conservation programs }\end{array}$} & -0.023 & 0.764 * & -0.003 & 0.317 & $0.933 * *$ & 0.130 \\
\hline & $(1.023)$ & $(2.146)$ & $(0.997)$ & $(1.373)$ & $(2.541)$ & (1.139) \\
\hline & [1.011] & [1.456] & [0.999] & [1.169] & [1.583] & [1.066] \\
\hline \multirow{3}{*}{$\begin{array}{l}\text { IMPORTANCE of soil } \\
\text { conservation }\end{array}$} & $0.195 *$ & 0.301 ** & $0.256^{*}$ & -0.039 & 0.131 & -0.027 \\
\hline & $(1.216)$ & (1.351) & $(1.291)$ & $(0.962)$ & (1.140) & $(0.974)$ \\
\hline & [1.340] & [1.571] & [1.468] & [0.943] & [1.217] & [0.960] \\
\hline \multirow{3}{*}{ TRANSFER TO RELATIVES } & 0.354 & 0.493 & 0.402 & -0.250 & 0.168 & 0.328 \\
\hline & (1.424) & (1.636) & (1.495) & $(0.779)$ & (1.182) & (1.388) \\
\hline & [1.193] & [1.278] & {$[1.222]$} & [0.883] & [1.087] & [1.177] \\
\hline \multirow{3}{*}{ PRO } & 0.001 & -0.007 & -0.015 & 0.008 & 0.003 & -0.011 \\
\hline & (1.000) & $(0.994)$ & $(0.985)$ & (1.008) & (1.003) & $(0.989)$ \\
\hline & [1.000] & [0.953] & [0.902] & [1.057] & [1.021] & [0.927] \\
\hline \multirow{3}{*}{ ACRES OWNED } & 0.053 & 0.005 & 0.036 & $0.109 *$ & 0.142 & -0.006 \\
\hline & (1.055) & (1.005) & (1.036) & (1.115) & (1.152) & $(0.994)$ \\
\hline & [1.210] & [1.018] & [1.138] & [1.481] & [1.667] & [0.979] \\
\hline \multirow{3}{*}{ ROW CROPS } & -0.335 & 0.228 & -0.383 & 0.980 * & -0.731 & -0.486 \\
\hline & $(0.715)$ & (1.256) & $(0.682)$ & (2.664) & $(0.482)$ & $(0.615)$ \\
\hline & [0.895] & [1.073] & [0.888] & [1.356] & [0.797] & {$[0.860]$} \\
\hline
\end{tabular}


Table 3. Cont.

\begin{tabular}{|c|c|c|c|c|c|c|}
\hline \multirow[b]{2}{*}{ Variable } & \multicolumn{6}{|c|}{ Coefficient (Odds Ratio) [Standardized Odds Ratio] } \\
\hline & $\begin{array}{l}\text { Controlling } \\
\text { Pollution }\end{array}$ & $\begin{array}{c}\text { Implementing } \\
\text { Conservation } \\
\text { Farming Practices }\end{array}$ & $\begin{array}{l}\text { Maintaining } \\
\text { Property }\end{array}$ & $\begin{array}{l}\text { Maintaining } \\
\text { High Crop Yield }\end{array}$ & $\begin{array}{c}\text { Using Natural } \\
\text { Resources Wisely }\end{array}$ & $\begin{array}{l}\text { Leaving Natural } \\
\text { Resources } \\
\text { Untouched }\end{array}$ \\
\hline INCOME & $\begin{array}{l}0.001 \\
(1.001) \\
{[1.055]}\end{array}$ & $\begin{array}{c}0.002 \\
(1.002) \\
{[1.113]}\end{array}$ & $\begin{array}{l}-0.003 \\
(0.997) \\
{[0.852]}\end{array}$ & $\begin{array}{c}0.003 \\
(1.003) \\
{[1.174]}\end{array}$ & $\begin{array}{l}0.001 \\
(1.001) \\
{[1.055]}\end{array}$ & $\begin{array}{l}0.006^{* *} \\
(1.006) \\
{[1.378]}\end{array}$ \\
\hline AGE & $\begin{array}{c}0.022 \\
(1.023) \\
{[1.328]}\end{array}$ & $\begin{array}{c}0.148 \\
(1.160) \\
{[1.210]}\end{array}$ & $\begin{array}{l}-0.107 \\
(0.898) \\
{[0.871]}\end{array}$ & $\begin{array}{l}-0.081 \\
(0.922) \\
{[0.901]}\end{array}$ & $\begin{array}{c}0.143 \\
(1.153) \\
{[1.203]}\end{array}$ & $\begin{array}{l}0.166 \\
(1.180) \\
{[1.239]}\end{array}$ \\
\hline Constant & $\begin{array}{c}0.228 \\
(1.256) \\
{[1.147]} \\
\end{array}$ & $\begin{array}{l}-0.124 \\
(0.884) \\
{[0.928]} \\
\end{array}$ & $\begin{array}{l}-0.038 \\
(0.963) \\
{[0.977]} \\
\end{array}$ & $\begin{array}{c}-0.493 * \\
(0.629) \\
{[0.757]}\end{array}$ & $\begin{array}{c}0.210 \\
(1.234) \\
{[1.135]} \\
\end{array}$ & $\begin{array}{l}-0.057 \\
(0.944) \\
{[0.966]} \\
\end{array}$ \\
\hline Nagelkerke R-squared ${ }^{1}$ & -1.102 & -0.688 & 0.882 & 0.297 & -0.134 & -1.060 \\
\hline
\end{tabular}

\section{Discussion}

This research contributes to previous PLS literature by suggesting farm land owners view stewardship as a responsibility owed to future generations and family more than community and society, and define stewardship as maintenance of the landowner's property. Despite most definitions of PLS including conservation of natural resources with consideration of both the future and society at large, and despite the fact that the NCFB is an organization dedicated to supporting farm communities [37], our respondents rarely attributed their stewardship responsibility to their community or society (objectives 1 and 2). Our findings build on previous studies that found respondents felt they owed their stewardship responsibility to future generations [31,42] and family [29]. Although some demographic groups such as Hispanics [29], a demographic largely absent in our study, may be more likely than others to view PLS as something owed to society or the public, public responsibility still appears to be relatively unimportant relative to family. These findings seem intuitive, particularly if respondents interpret questions about future generations as referring to their own progeny. Given that PLS can influence landowner willingness to adopt socially desirable land management practices without financial incentives [19], future research should investigate the extent to which perceived responsibility to future generations reflects a sense of responsibility to the future society at large versus responsibility to one's own heirs, and explore ways to promote individual, familial, and public responsibility simultaneously as part of stewardship.

Our finding that maintaining property was the behavior most associated with stewardship is consistent with the body of literature finding that landowners believe a clean and neat farm is a good farm, and thus the sign of a good steward (objective 3). Egoz et al. [43] suggest traditional stewardship ideals in New Zealand include maintaining a tidy and efficient farming landscape, while Nassauer [44] found similar ideals prevailed in more urban areas of North America. Furthermore, landowners may earn respect in the farming community by demonstrating that their farm is maintained and successful through keeping it tidy [43]. Although this research adds to the limited research that exists related to concepts of stewardship, longitudinal meta-analyses could provide valuable insight regarding if and how views of stewardship (i.e., who it is owed to and how it is defined) are evolving over time.

Respondents may have been more likely to associate stewardship with conservation (i.e., using natural resources wisely) than preservation (i.e., leaving natural resources untouched) because the majority of their total household income depended on active use of the land. Conservation efforts aimed at sustaining working lands, rural character, and agriculture would benefit from framing their efforts in terms of actively conserving lands through stewardship versus passively setting them aside [38,39]. The positive relationship between INCOME and viewing PLS as leaving natural resources untouched, and between INCOME and owing stewardship to the land suggests preservation of the land for the sake of the land (non-anthropocentric motives) [38,39] may be a useful way to frame conservation initiatives in contexts involving high-income landowners. 
The prevalence of private land conservation programs in the US, which pay private landowners to implement specific conservation objectives in exchange for payments, and the cost of maintaining working private lands, may help explain why the majority of respondents indicated payments would make them better stewards of the land (objective 4). Given that over $40 \%$ of our respondents had participated in a conservation incentive programs previously, the concept of payments to improve stewardship was familiar. Such programs may be common enough to explain why even respondents who indicated they had not participated in a conservation program within the previous 5 years associated payments with stewardship. Although conservation incentive programs may be essential tools for protecting and securing ecosystem services on private lands, use of such programs can come with risks. Such programs may create expectations that stewardship should only be provided if it is paid for (this study; [45]) and research in related fields suggests that once payments are started, organizations may be obligated to continue payments in order to maintain the management practices required to obtain their conservation objectives [46-48]. We suggest future inquiry addressing the degree to which payments for conservation actions shape views of stewardship and stewardship behaviors.

The prevalence of conservation programs that focus specifically on soil conservation [13] may explain why private landowners associate stewardship with soil conservation practices. This finding has implications for the rapidly emerging attempts to pay landowners for diverse ecosystem services including endangered species habitat [49,50] and ground water management [51], as it may suggest that the increase and diversification of payment programs may help broaden the scope of what private landowners associate with stewardship.

The negative relationship between AGE and yourself, in particular, suggests changing land ownership demographics related to intergenerational land transfers [52] may have major implications for the role of PLS in conservation in the future. As much as US $\$ 41$ trillion of wealth in the US will be transferred to the next generation by 2050 [53] either via succession or estate planning [54]. The majority of this wealth is in the form of non-financial assets such as property and land [53]. The altruistic behavioral framework suggests that intergenerational land transfers occur because landowners care about the wellbeing of other individuals (typically their children) [54,55]. Thus, as those landowners age, they begin to think of their land more so in terms of others rather than themselves, and make plans for succession or bequest of their land to the next generation. This result suggests that as intergenerational land transfers occur, the new generation of landowners will likely be focused on stewardship for their own and their families' benefit, and the corresponding PLS narrative may be a more effective conservation tool if it changes to account for this.

\section{Conclusions}

In order to use the stewardship framework to communicate effectively with private landowners and farm operators, and successfully engage them in conservation without direct payments, conservation professionals may benefit from approaching landowners using a framework with broad appeal to their sense of stewardship. Our findings suggest framing PLS as service to future generations and family would likely appeal to and be effective with a variety of farm land owners and operators. However the stewardship messages could be tailored to different groups to maximize effectiveness. For example, younger landowners may be more motivated by stewardship when it is framed as a responsibility, and overall benefit, to themselves, and PLS programs including monetary payments might increase receptivity to conservation initiatives among young farmers.

Acknowledgments: Funding and support for our research were provided by the Office of the Secretary of Defense, Texas A\&M University, The Dean's Office of the College of Natural Resources at North Carolina State University, and the North Carolina Farm Bureau. We thank William (Billy) Bridges (Clemson University) and Xiaodong Chen (University of North Carolina, Chapel Hill) for their statistics assistance. We would also like to thank Tim Jones and Susan Woodall of the USDA Farm Service Agency, and Don Riley of the USDA Natural Resources Conservation Service, for providing information about Farm Bill programs in North Carolina. Lastly, we thank the North Carolina Farm Bureau staff, especially Chester Lowder, for their invaluable assistance with implementing 
our survey and North Carolina Farm Bureau county advisory board members for the generosity of their time in participating in our study.

Author Contributions: Shari L. Rodriguez and M. Nils Peterson conceived and designed this study with input from Erin O. Sills, Fred W. Cubbage and Howard D. Bondell; Shari L. Rodriguez performed the research; Shari L. Rodriguez, M. Nils Peterson and Howard D. Bondell analyzed the data. Shari L. Rodriguez wrote the paper with assistance and edits from M. Nils Peterson, Erin O. Sills, Fred W. Cubbage, and Howard D. Bondell.

Conflicts of Interest: The authors declare no conflict of interest.

\section{References}

1. Kamal, S.; Grodzinska-Jurczak, M.; Brown, G. Conservation on private land: A review of global strategies with a proposed classification system. J. Environ. Plan. Manag. 2015, 58, 576-597. [CrossRef]

2. Davis, D.K. Neoliberalism, environmentalism, and agricultural restructuring in Morocco. Geogr. J. 2006, 172, 88-105. [CrossRef]

3. Klopp, J.M. Pilfering the public: The problem of land grabbing in contemporary Kenya. Afr. Today 2000, 47, 7-26. [CrossRef]

4. Lamprey, R.H.; Reid, R.S. Expansion of human settlement in Kenya's Maasai Mara: What future for pastoralism and wildlife? J. Biogeogr. 2004, 31, 997-1032. [CrossRef]

5. Lesorogol, C.K. Privatizing pastoral lands: Economic and normative outcomes in Kenya. World Dev. 2005, 33, 1959-1978. [CrossRef]

6. Liverman, D.M.; Vilas, S. Neoliberalism and the environment in Latin America. Annu. Rev. Environ. Resour. 2006, 31, 327-363. [CrossRef]

7. Thongmanivong, S.; Fujita, Y. Recent land use and livelihood transitions in northern Laos. Mount. Res. Dev. 2006, 26, 237-244. [CrossRef]

8. US Department of Agriculture (USDA). Major Uses of Land in the United States. Available online: http:/ / www.ers.usda.gov/publications/EIB14/eib14.pdf (accessed on 13 March 2012).

9. Lockwood, J.A. The intent and implementation of the Endangered Species Act: A matter of scale. In Private Property and the Endangered Species Act; Shogren, J.F., Ed.; University of Texas Press: Austin, TX, USA, 1998; pp. 70-91.

10. Turner, J.F.; Rylander, J.C. The private lands challenge: Integrating biodiversity conservation and private property. In Private Property and the Endangered Species Act; Shogren, J.F., Ed.; University of Texas Press: Austin, TX, USA, 1998; pp. 92-137.

11. Ruhl, J.B.; Kraft, S.E.; Lant, C.L. The Law and Policy of Ecosystem Services; Island Press: Washington, DC, USA, 2007.

12. Scott, J.M.; Gobel, D.D.; Davis, F.W. The Endangered Species Act at Thirty, Volume 2: Conserving Biodiveristy in Human-Dominated Landscapes; Island Press: Washington, DC, USA, 2006.

13. Karlen, D.L.; Gardner, J.C.; Rosek, M.J. A soil quality framework for evaluating the impact of CRP. J. Prod. Agric. 1998, 11, 56-60. [CrossRef]

14. US Department of Agriculture (USDA) Farm Service Agency. Conservation Reserve Program Annual Summary and Enrollment Statistics, Fiscal Year 2012. Available online: https: / www.fsa.usda.gov / Assets / USDA-FSA-Public/usdafiles/Conservation/PDF/summary12.pdf (accessed on 24 August 2016).

15. Stubbs, M. Conservation Reserve Program (CRP): Status and Issues. Congressional Research Service Report 7-5700. Available online: http://nationalaglawcenter.org/wp-content/uploads/assets/crs/R42783.pdf (accessed on 29 June 2016).

16. Carson, R. Silent Spring; Houghton Mifflin: Boston, MA, USA, 1962.

17. Wagner, K.K.; Schmidt, R.H.; Conover, M.R. Compensation programs for wildlife damage in North America. Wildl. Soc. Bull. 1997, 25, 312-319.

18. Jackson-Smith, D.; Kreuter, U.; Krannich, R.S. Understanding the multidimensionality of property rights orientations: Evidence from Utah and Texas ranchers. Soc. Nat. Resour. 2005, 18, 587-610. [CrossRef]

19. Kreuter, U.P.; Nair, M.V.; Jackson-Smith, D.; Conner, J.R.; Johnston, J.E. Property rights Orientations and rangeland management objectives: Texas, Utah, and Colorado. Rangel. Ecol. Manag. 2006, 59, $632-639$. [CrossRef] 
20. Worrell, R.; Appleby, M.C. Stewardship of natural resources: Definition, ethical and practical aspects. J. Agric. Environ. Ethics 2000, 12, 263-277. [CrossRef]

21. Roberts, B.R. Land Care Manual; New South Wales University Press: Sydney, Australia, 1992.

22. Davis, G.E. National Park stewardship and 'vital signs' monitoring: A case study from Channel Islands National Park, California. Aquat. Conserv. 2005, 15, 71-89. [CrossRef]

23. Milich, L. Resource mismanagement versus sustainable livelihoods: The collapse of the Newfoundland cod fishery. Soc. Nat. Resour. 1999, 12, 625-642. [CrossRef]

24. Mburu, J.R.; Birner, R. Emergence, adoption, and implementation of collaborative wildlife management or wildlife partnerships in Kenya: A look at conditions for success. Soc. Nat. Resour. 2007, 20, 379-395. [CrossRef]

25. Carr, A. Grass Roots and Green Tape: Principles and Practices of Environmental Stewardship; Federation Press: Canberra, Australia, 2002.

26. President's Council on Sustainable Development. Towards a Sustainable America: Advancing Prosperity, Opportunity and Healthy Environment for the 21st Century. Available online: https: / clinton2.nara.gov / PCSD / Publications/tsa.pdf (accessed on 14 May 2014).

27. Earl, G.; Curtis, A.; Allan, C. Towards a duty of care for biodiversity. Environ. Manag. 2010, 45, 682-696. [CrossRef] [PubMed]

28. Peterson, T.R.; Horton, C.C. Rooted in the soil: How understanding the perspectives of landowners can enhance the management of environmental disputes. Q. J. Speech 1995, 81, 139-166. [CrossRef]

29. Peterson, M.N.; Peterson, T.R.; Lopez, A.; Liu, J. Views of private-land stewardship among Latinos on the Texas-Tamaulipas border. Environ. Commun. 2010, 4, 406-421. [CrossRef]

30. Burger, J. Restoration, stewardship, environmental health and policy: Understanding stakeholders perceptions. Environ. Manag. 2002, 30, 631-640. [CrossRef] [PubMed]

31. Davies, B.B.; Hodge, I.D. Exploring environmental perspectives in lowland agriculture: A methodology study in East Anglia, UK. Ecol. Econ. 1987, 61, 323-333. [CrossRef]

32. North Carolina Wildlife Resources Commission. North Carolina Wildlife Action Plan. Available online: http: / / www.ncwildlife.org/plan\#6721629-projects (accessed on 26 March 2012).

33. U.S. Department Agriculture (USDA) of National Agricultural Statistics Service. State Agriculture Overview: North Carolina. Available online: http://www.nass.usda.gov/Statistics_by_State/Ag Overview / AgOverview_NC.pdf (accessed on 5 January 2012).

34. Brown, M.; New, B.D. North Carolina, 2010 Forest Inventory and Analysis Factsheet. E-Science Update SRS-044. 2012. Available online: http:/ / www.treesearch.fs.fed.us/pubs/40000 (accessed on 23 May 2014).

35. US Department of Agriculture (USDA) Farm Agency. Conservation Reserve Program Statistics-CRP Enrollment and Rental Payments by State, 1986-2015. Available online: https: / /www.fsa.usda.gov / programs-and-services / conservation-programs / reports-and-statistics / conservation-reserve-program-statistics/index (accessed on 24 August 2016).

36. Straka, T.J.; Kilgore, M.A.; Jacobson, M.G.; Greene, J.L.; Daniels, S.E. Influence of financial incentive programs in sustaining wildlife values. Hum. Dimens. Wildl. 2007, 12, 197-199. [CrossRef]

37. North Carolina Farm Bureau (NCFB). History. Available online: http:/ / www.ncfb.org/about/history.cfm (accessed on 13 March 2012).

38. Passmore, J. Man's Responsibility for Nature: Ecological Problems and Western Traditions; Gerald Duckworth: London, UK, 1974.

39. Norton, B.G. Conservation and preservation: A conceptual rehabilitation. Environ. Ethics 1986, 8, $195-220$. [CrossRef]

40. US Department of Agriculture (USDA) Census of Agriculture. North Carolina. Available online: http:/ / www.agcensus.usda.gov / Publications/2007 /Full_Report/Volume_1,_Chapter_1_State_Level/ North_Carolina/ (accessed on 5 June 2012).

41. Cameron, A.C.; Windmeijer, F.A.G. An R-squared measure of goodness of fit for some common nonlinear regression models. J. Econ. 1997, 77, 329-342. [CrossRef]

42. Tyson, C.B.; Broderick, S.; Snyder, L. A social marketing approach to landowner education. J. For. 1998, 96, 34-40.

43. Egoz, S.; Bowring, J.; Perkins, H.C. Making a "mess" in the countryside: Organic farming and the threats to sense of place. Landsc. J. 2006, 25, 54-66. [CrossRef] 
44. Nassauer, J.I. Cultural sustainability: Aligning aesthetics and ecology. In Placing Nature: Cuture and Landscape Ecology; Nassauer, J.I., Ed.; Island Press: Washington, DC, USA, 1997; pp. 65-84.

45. Redford, K.H.; Adams, W.M. Payment for ecosystem services and the challenge of saving nature. Conserv. Biol. 2009, 23, 785-787. [PubMed]

46. Wagner, M.; Kaiser, R.; Kreuter, U.; Wilkins, R.N. Managing the commons Texas style: Wildlife management and groundwater associations on private lands. J. Am. Water Resour. Assoc. 2007, 43, 698-711. [CrossRef]

47. Ferraro, P.J.; Kiss, A. Direct payments for biodiversity conservation. Science 2002, 298, 1718-1719. [CrossRef] [PubMed]

48. Karanth, K.U.; Madhusudan, M.D. Mitigating human wildlife conflicts in southern Asia. In Making Parts Work: Strategies for Protecting Tropical Nature; Island Press: Covelo, CA, USA, 2002; pp. 395-408.

49. Rodriguez, S.L.; Peterson, M.N.; Cubbage, F.W.; Bondell, H.D.; Sills, E.O. Private landowner interest in market-based incentive programs for endangered species habitat conservation. Wildl. Soc. Bull. 2012, 36, 469-476. [CrossRef]

50. Sorice, M.; Oh, C.; Gartner, T.; Snieckus, M.; Johnson, R.; Donlan, J. Increasing participation in incentive programs for biodiversity conservation. Ecol. Appl. 2013, 23, 1146-1155. [CrossRef] [PubMed]

51. Turpie, J.K.; Marais, C.; Blignaut, J.N. The working for water programme: Evolution of a payments for ecosystem services mechanism that addresses both poverty and ecosystem service delivery in South Africa. Ecol. Econ. 2008, 65, 788-798. [CrossRef]

52. Best, C. America's private forests: Challenges for conservation. J. For. 2002, 100, 14-17.

53. Brill, B. Preparing for the intergenerational transfer of wealth: Opportunities and strategies for advisors. J. Pract. Estate Plan. 2003, 5, 23-30.

54. Harris, J.M.; Mishra, A.K. US farm succession and the process of transferring land ownership. In Proceedings of the 2016 Agricultural and Applied Economics Association Annual Meeting, Boston, MA, USA, 31 July-2 August 2016.

55. Cox, D. Motives for private income transfers. J. Polit. Econ. 1987, 95, 508-546. [CrossRef]

(C) 2018 by the authors. Licensee MDPI, Basel, Switzerland. This article is an open access article distributed under the terms and conditions of the Creative Commons Attribution (CC BY) license (http:/ / creativecommons.org/licenses/by/4.0/). 